\title{
Compositional Peculiarities of Planning the Pochayiv Lavra Architectural Ensemble
}

\begin{abstract}
The article highlights the process of the formation of the Pochayiv Lavra architectural ensemble and the role of the shrine in the history and culture of Ukraine. The historical preconditions for the construction, architectural and planning structure of the complex have been analyzed. The relevance of architectural and planning structure of the Lavra to socio-political factors that influenced the architecture of the complex has been established. The Lavra complex planning has been analysed and its compositional dominants have been determined.
\end{abstract}

Keywords: volumetric and spatial composition, listed building, social and political processes, baroque, classicism, art nouveau, architectural ensemble, cathedral

\section{Introduction}

Architecture can reflect the periods of the heyday and decline of society. The Pochayiv Lavra architectural ensemble, which has been formed for centuries, shows all social and political processes that have been taking place in Western Ukraine since the $15^{\text {th }}$ century. During its long history the Lavra has always been in the centre of all historical and political events of the region, played an important role in promoting Christian values, and has been the centre of education and culture.

The purpose of the article is to highlight the process of forming the architectural ensemble of the Pochayiv Lavra, analyse architectural and planning structure of the complex and determine its compositional dominants.

2. Setting the problem and relationship with important scientific and practical tasks

The world-famous Christian spiritual centre, the Holy Dormition Pochayiv Lavra, is an important part of the spiritual and cultural life of the Ukrainian people. At the time of its foundation it was the centre of Ukrainian Orthodoxy. In May 2016 Ternopil Regional Council made an appeal to the President and Cabinet of Ministers concerning the return of the state reserve status to the Pochayiv Lavra [12]. In terms of establishing civilizational choice of Ukraine and the necessity to solve political, national and cultural problems of modern state development it is very important to know the history of one's own region, the history of one's own sacred places.

\section{The analysis of recent research and publications}

The Development of Ukrainian architecture as well as the architecture of the Pochayiv Lavra complex was studied in "The History of Ukrainian Architecture" [1]. The illustrated essays on the shrine $[2,3]$ and its significance in the history of Ukra- inian culture and Ukrainian national revival have been explored by historians, ethnographers, architects [4-8]. However, the architectural and planning structure of the Pochayiv Lavra, its characteristics and determination of architectural dominants have not been presented in the science of art history which specifies the actuality of this research.

Objectives of the research: to explore the process of forming the Pochayiv Lavra architectural complex; to analyse the ensemble planning and determine its compositional dominants.

\section{The main part}

The first written mention of the monastery belongs to 1450 (other sources give the date 1527). The development of the monastery began in the end of the $16^{\text {th }}$ century under the patronage of a local land-owning lady Anna Hoiska [3, p. 131-136].

In the $17^{\text {th }}$ century the monastery was a fortified defensive structure, it was surrounded by stone and wooden walls with towers that were adjacent to the church and palisade in the south. The yard was free of buildings. Near the northern and eastern curtain defensive walls one-storey buildings of cells stood [1, p. 168] (ill. 1).

From 1713 to 1832 , when the monastery of Pochayiv belonged to the Greek-Catholic church, the greatest amount of building work was carried out at the site of the architectural 
shows that the biggest change in the volumetric and spatial composition of the ensemble took place in the $18^{\text {th }}$ century in the times of Basilian monks.

2. It has been revealed that besides the sacred function the monastery also performed defensive, cultural, social, political, and economic functions. The complex included utility and production buildings.

3. The main focus of the complex which towered over all the buildings was the cathedral. The refectory dominated residential and utility buildings. The bell tower as an essential compositional centre in its turn dominated the refectory. The Holy Gate is located at one of the lowest points of the monastery territory. Thus, the building work was carried out in accordance with the functional areas and the construction bears a clear hierarchical system.

\section{BIBLIOGRAPHY}

[1] Tymofiyenko V.I., Istoriya ukrayins'koyi arkhitektury [The History of Ukrainian Architecture]. Kyiv, Tekhnika Publ., 2003, 472 p.

[2] Chernykhivs'kyy H.I., Pochayivs'ka Svyato-Uspens'ka Lavra [The Holy Dormition Pochayiv Lavra]. Ternopil, Zbruch, 2006 Publ., 48 p.

[3] Nizovs'kyy A.Yu., Sto velykykh chudes Ukrayiny [One Hundred Great wonders of Ukraine]. Kyiv, Ariy Publ., 2010, 416 p.

[4] Luk"yanenko S. V., Pochayivs'ka Lavra $v$ istoriyi ukrayins'koyi kul'tury [The Pochayiv Lavra in the History of Ukrainian Culture] Nauk. Konferentsiya «Relihiya i tserkva $\vee$ natsional'nomu vidrodzhenni Ukrayiny" [The Scientific Conference "Religion and Church in the National Revival of Ukraine"]. Ternopil, 1993, pp. 44-46

[5] Novak O., Tserkovne zhyttya u Zakhidniy Ukrayini y na pravoberezhzhi u druhiy polovyni XVII-XVIII st. [Church life in Western Ukraine and in Right-bank Ukraine in the Second Half of the 17th-18th Centuries] Istoriya Ukrayiny - The History of Ukraine, 2004, Vol. 17 (369), May, pp. 13-15
[6] Shvalyuk I., Rol' dukhovenstva v relihiyno-tserkovnomu ta hromads, komu zhytti Kremenets'koho povitu mizhvoyennoho periodu [The Role of Clergy in the Religious and Public Life of Kremenets County during the Interwar Period] Naukovi zapysky TNPU im. V. Hnatyuka. Seriya: Istoriya [Scientific Issuses of Ternopil Volodymyr Hnatiuk National Pedagogical University. Series: History]. Ternopil, TNPU Publ., 2014, Vol. 1(3), pp. 62-64

[7] Duda I., Mel'nychuk B., Zemlya Ternopil's'ka. Turystychnyy putivnyk [Ternopil Region. Travel Guide]. Ternopil, 2003, $368 \mathrm{p}$.

[8] Dyachok O. M., Sakral'ni svyatyni Ternopil'shchyny [Sacred Shrines of Ternopil Region]. Naukovi zapysky TNPU im. V. Hnatyuka. Seriya: Mystetstvoznavstvo [Scientific Issuses of Ternopil Volodymyr Hnatiuk National Pedagogical University]. Ternopil, TNPU Publ., 2013, Vol. 2, pp. 215-219.

[9] Dudar V.L., Hromads'ko-politychnyy ta kul'turnyy vplyv Pochayivs'koho monastyrya na naselennya Volyni (XIX pochatok XX st.). Avtoref. dys. na zdobuttya stupenya kand. istor. nauk: 07.00.01 [Socio-political and Cultural Influence of the Pochayiv Monastery on the population of Volyn (19th - the early 20th Century)]. Pereyaslav-Khmelnytskyy, 2008, $17 \mathrm{p}$.

[10] Holodyuk N. V., Pravoslavni monastyri Rivnens'koyi ta Ternopil's'koyi oblastey yak ob"yekty palomnytstva ta relihiynoho turyzmu [Orthodox Monasteries of Rivne and Ternopil Regions as Objects of Pilgrimage and Religious Tourism]. Available at: http://www.rusnauka.com/30 NTP 2015/ Istoria/2 I 99665.doc.htm. (accessed 20.03.2017).

[11] Hordiyenko H., Osnovni symvoly ukrayins'koho baroko [Major Symbols of Ukrainian Baroque] Naukovi zapysky TNPU im. V. Hnatyuka. Seriya: Istoriya [Scientific Issuses of Ternopil Volodymyr Hnatiuk National Pedagogical University. Series: History]. Ternopil, TNPU Publ., 2014, Vol. 2(2), pp. 142-143.

[12] Ternopil's'ki deputaty vymahayut' u Poroshenka povernuty Pochayivs'ku lavru derzhavi [Ternopil Deputies Demand from Poroshenko to Return Pochayiv Lavra to the State]. Available at: http://khm.depo.ua /ukr/ternovpol/-12052016141800 (accessed 18.04.2017). 